\title{
Coronary Subclavian Steal Syndrome: Diagnosis by Routine Chest Computed Tomography and Percutaneous Treatment with Subclavian Artery Stenting
}

\author{
Koroner Subklavyan Çalma Sendromu: Rutin Göğüs Tomografisi ile Tanısı, Subklavyan Arter \\ Stentleme ile Perkütan Tedavisi
}

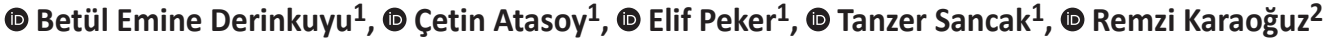 \\ ${ }^{1}$ Ankara University Faculty of Medicine, Department of Radiology, Ankara, Turkey \\ ${ }^{2}$ Ankara University Faculty of Medicine, Department of Cardiology, Ankara, Turkey
}

\section{Abstract}

The present case is a 51-year-old woman with complaints of chest and left shoulder pain during physical activity for the last two months. She had a coronary artery bypass grafting one year ago. Chest computed tomography and angiographic examination demonstrated significant stenosis on the left subclavian artery. Percutaneous transluminal angioplasty and stent implantation was successfully achieved to the left subclavian artery, resulted with restoration of myocardial perfusion.

Key Words: Subclavian Steal, Computed Tomography, Angioplasty, Coronary Artery

\section{Öz}

Bu yazıda son 2 aydır fiziksel aktivite ile ortaya çıkan göğüs ve sol omuz ağrısı tarifleyen 51 yaşındaki kadın hasta sunulmaktadır. Hastamız 1 yıl önce koroner arter bypass ameliyatı geçirmiştir. Şikayetleri üzerine yapılan göğüs tomografisinde ve anjiografik incelemede sol subklavyan arterde darlık saptanmıştır. Sol subklavyan arterdeki darlık düzeyine perkütan translüminal anjiyoplasti ile stent yerleştirilmiş̧ir. İşlem sonrasında miyokardiyal perfüzyon normale dönmüştür.

Anahtar Kelimeler: Subklavyan Çalma, Bilgisayarlı Tomografi, Anjiyoplasti, Koroner Arter

\section{Introduction}

The left internal mammary artery (LIMA) is the most desired arterial bypass graft for myocardial revascularization. LIMA is anastomosed to the left anterior descending artery (LAD) more often $(1,2)$. The coronary subclavian steal syndrome (CSSS) is an infrequent but severe source of postoperative recurrent angina which is caused by significant stenosis or total occlusion of the left subclavian artery before the LIMA ostium $(3,4)$. The blood flow through LIMA decreases in time and occasionally reverses leading to myocardial ischemia (5). We report a case of CSSS diagnosed by a chest computed tomography (CT) and treated with subclavian artery stenting.

\section{Case Report}

A 51-year-old female presented with a two-month history of paresthesia of the left upper extremity, exertional chest and left shoulder pain, and breathlessness. She had several risk factors for ischemic heart disease including a positive family history, type 2 diabetes mellitus, and hypercholesterolemia. Fourteen months ago she had been diagnosed as an acute coronary syndrome, and a stenosis of the proximal LAD, had

Address for Correspondence/Yazışma Adresi: Betül Emine Derinkuyu MD,

Ankara University Faculty of Medicine, Department of Radiology, Ankara, Turkey

Phone: +90 5053514994 E-mail: betulemineyildiz@gmail.com ORCID ID: orcid.org/0000-0003-2434-1398

Received/Geliş Tarihi: 19.07.2017 Accepted/Kabul Tarihi: 27.04.2018

- Copyright 2018 Ankara University Faculty of Medicine

Journal of Ankara University Faculty of Medicine is published by Galenos Publishing House.

All content are under CC BY-NC-ND license. 
been treated by an endovascular stent. Four months later, a recurrent stenosis occurred in the same artery and the stent was totally occluded. A LIMA-LAD bypass grafting was performed. Ten months after this operation, the same symptoms recurred, but coronary angiography showed a patent LAD-LIMA graft and normal left circumflex and right coronary arteries. A contrast-enhanced chest CT was ordered to explain the patient's symptoms. CT examination was done with an 8-MDCT scanner (LightSpeed Ultra, GE Healthcare). The findings were normal except for a discernible stenosis in the proximal portion of the left subclavian artery (Figure 1a). The degree of stenosis was estimated to be $60-70 \%$ on the sagittal and coronal reformatted images (Figure 1b).

An exertional technetium-99m MIBI myocardial perfusion radionuclide study showed a focal ischemic area in the apicolateral part of the left ventricle which was in the territory of the LAD-LIMA graft. A selective left subclavian arteriography confirmed the stenosis in the proximal portion of the left subclavian artery (Figure 2). Although the LIMA was patent, its flow was noticeably reduced. A $\phi 7 \mathrm{~mm} \times 40 \mathrm{~mm}$ balloonexpandable stent (Express Vascular LD, premounted stent system, Boston Scientific Ballybrit Business Park, Galway, Ireland) was placed into the stenotic area. A control angiogram showed no residual stenosis and improved flow in LIMA (Figure 2). Patient's symptoms resolved soon after this therapy. Six days after stent insertion, repeat exertional technetium-99m MIBI myocardial perfusion study showed restoration of the normal perfusion in the previously ischemic apicolateral part of the left ventricle.

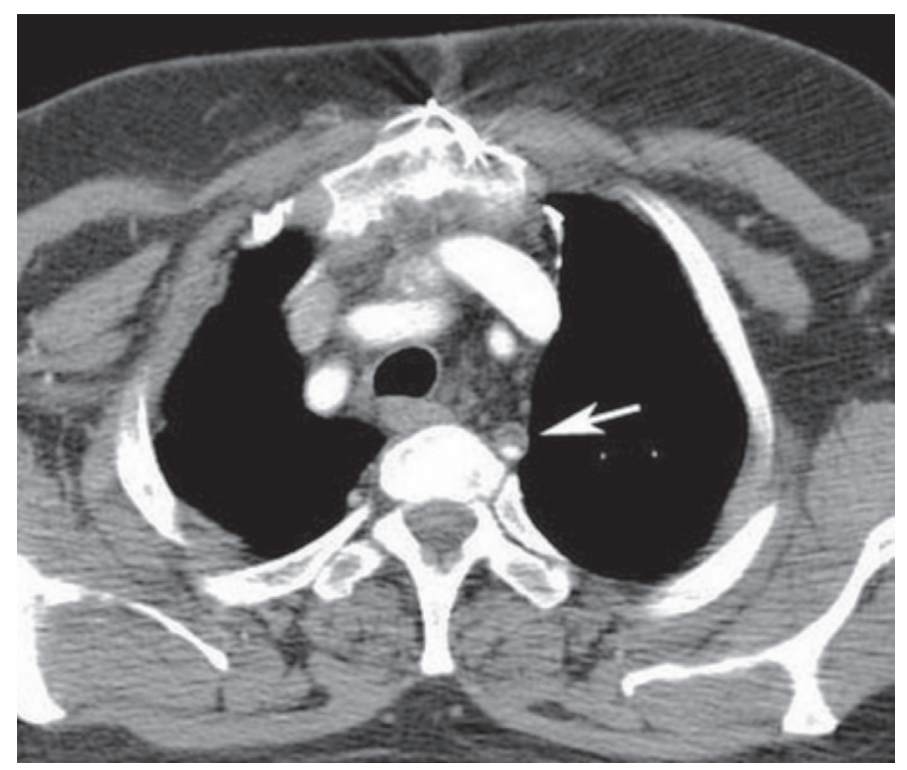

Figure 1a: Contrast-enhanced chest computed tomography, axial image, shows stenosis at the proximal part of the left subclavian artery (arrow). Note also the sternal wires and metallic clips in the mediastinum

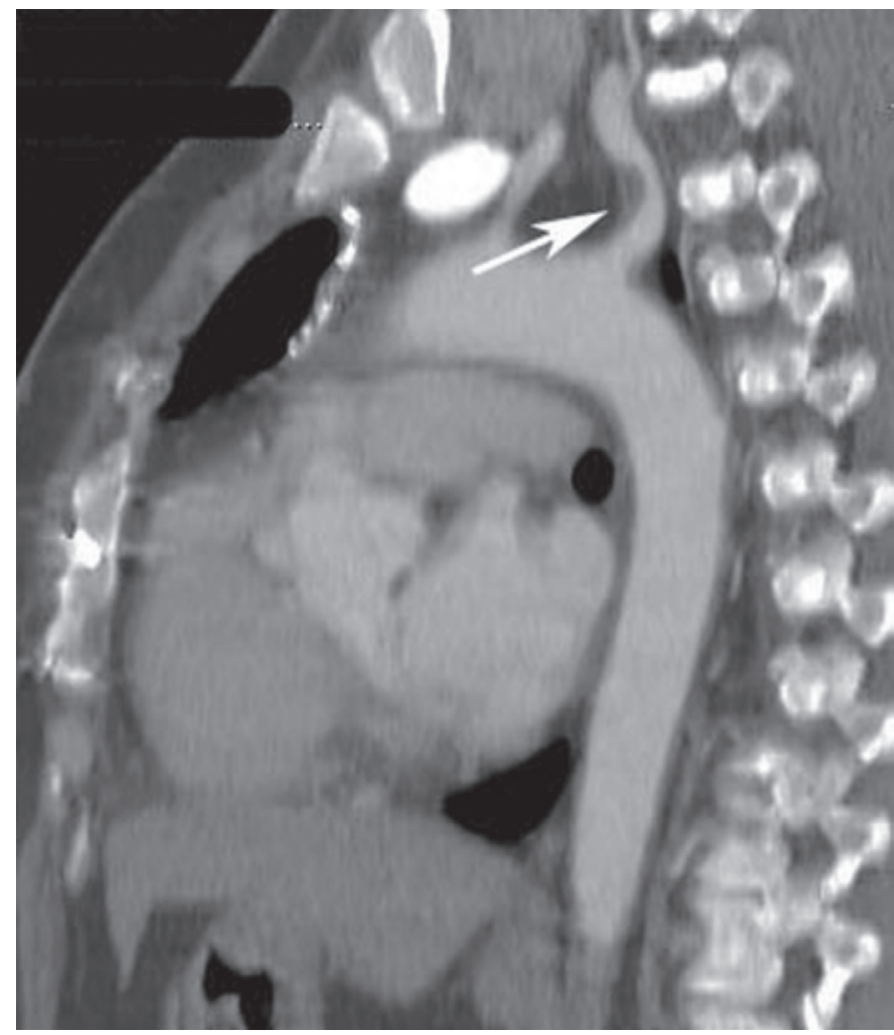

Figure 1b: Sagittal reformatted image of contrast enhanced chest computed tomography, confirms the presence of significant stenosis (arrow) in the proximal left subclavian artery

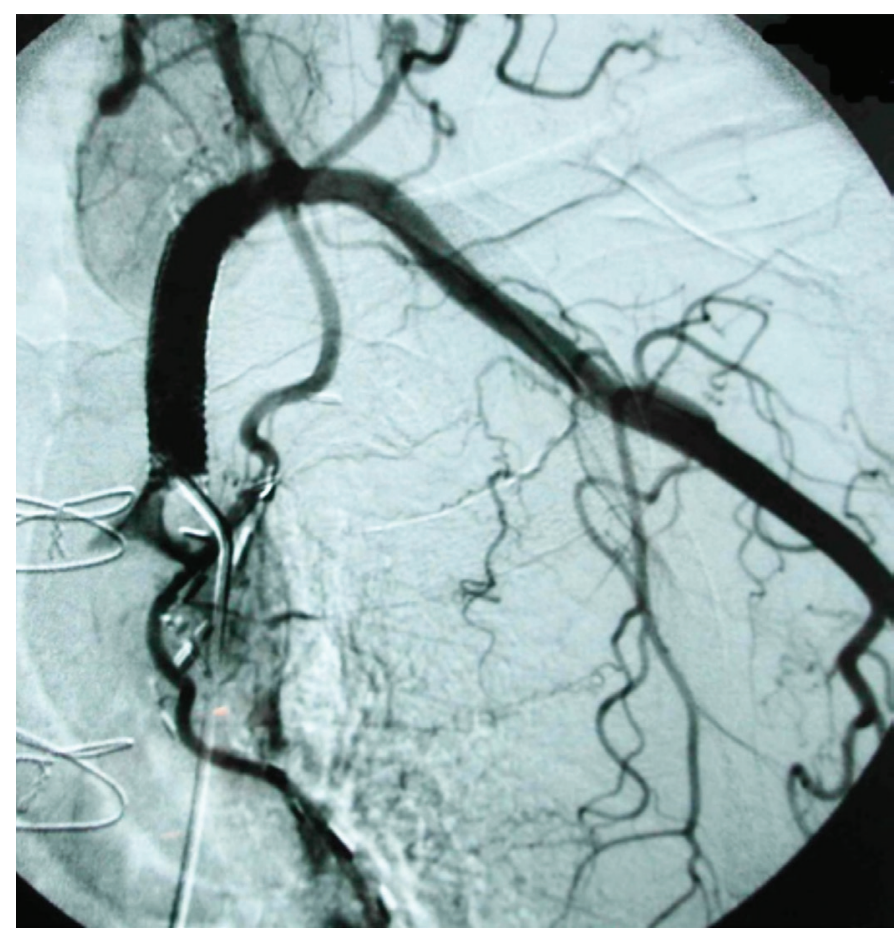

Figure 2: Selective left subclavian arteriography after the stent placement shows fully expanded stent with no residual stenosis in proximal left subclavian artery lumen and restored flow in left internal mammary artery 


\section{Discussion}

The brachiocephalic and subclavian artery obstructions have received increased attention due to the use of internal mammary conduits for coronary bypass surgery (6). The wellknown vertebral subclavian steal syndrome arises due to reverseflow in the vertebral artery as blood is shunted into the brachial circulation $(5,6)$. CSSS, which is much rarer, is caused by reversal of flow within LIMA because of a proximal left subclavian artery stenosis $(5,6)$. After LIMA graft surgery to the coronary artery, the vascular segment between the origin of the subclavian artery and the coronary artery functionally turns out to be a part of the coronary circulation and therefore stenosis in every part of this segment could straightforwardly precipitate myocardial ischemia $(5,6)$.

The frequency of the CSSS has been reported to range from $0.4-2 \%$ in coronary artery bypass graft patients (3). Most patients present with recurrent angina pectoris after a variable asymptomatic period. An early presentation of the syndrome as in this case is probably due to the existence of the subclavian stenosis at the time of coronary revascularization, which raises the question of whether a subclavian aortogram should be obtained in every surgical patient involving the use of the internal mammary artery (5). Most authors recommend that all candidates for coronary artery bypass surgery need blood pressure measurements obtained in both arms and auscultation for subclavian bruits (7). If there is a positive clinical finding, an arch aortography or CT angiography should be ordered. In older patients with diffuse atherosclerosis in whom the possibility of subclavian atherosclerosis is high, the subclavian artery and LIMA should be routinely imagined before the surgery (5). If the subclavian artery and LIMA flows are inadequate, endovascular intervention to get better the flow should be done before using the LIMA as a graft.

Although the diagnosis of CSSS relies upon demonstration of reversed flow in the LIMA on angiography (5), it may be suspected on other imaging methods. CT is commonly employed in patients with chest pain. This case illustrates the need to scrutinize the proximal subclavian artery for possible stenosis or occlusion in coronary artery bypass patients undergoing chest CT for unexplained chest pain. The same recommendation holds for the more common situation where a CT angiography has been ordered for the noninvasive follow-up of the coronary artery bypass grafts. Particularly in symptomatic patients, patency of the grafts may not guarantee normality of the coronary circulation, unless the parent subclavian artery has also been evaluated.

The various treatment modalities of CSSS are all directed towards treating the subclavian artery stenosis. Early reports on the treatment of CSSS focused on the role of surgery with carotid- subclavian or carotid- axillary bypass grafting as the preferred procedure $(3,6)$. Thereafter, the use of percutaneous transluminal angioplasty has been advocated $(5,6,8)$. Balloon angioplasty for subclavian artery stenosis was initially explained in the early 1980 s as an alternative to surgical management and subsequent reports show that both early and long-term patency rates were comparable to surgery $(5,8,9,10)$. Since then percutaneous transluminal angioplasty has become more common as a choice to surgery. The introduction of stenting techniques has further developed the results of angioplasty $(5,10)$.

To conclude, in patients with recurrent angina following LIMA-LAD grafting, left subclavian artery stenosis should be thought as a possible cause for recurrent myocardial ischemia, particularly in patients with peripheral vascular disease. Awareness of this possibility may lead to a straight-forward diagnosis on contrast-enhanced multidetector CT of the chest, which has been increasingly used in patients with chest pain.

\section{Ethics}

Informed Consent: It was taken.

\section{Authorship Contributions}

Surgical and Medical Practices: T.S., R.K., Concept: B.E.D., Ç.A., Design: B.E.D., Ç.A., Data Collection or Processing: B.E.D., E.P., Analysis or Interpretation: B.E.D., C..A., Literature Search: B.E.D., E.P., Writing: B.E.D., C..A.

Conflict of Interest: No conflict of interest was declared by the authors.

Financial Disclosure: The authors declared that this study received no financial support.

\section{References}

1. Demir I, Yilmaz H, Sancaktar 0. Coronary subclavian steal syndrome: treatment by stenting of the left subclavian artery. Jpn Heart J 2002;43:7984.

2. Vranic $\mathrm{M}$, Vaughn $\mathrm{PL}$, Lobato $\mathrm{AC}$, et al. Intraoperative subclavian artery stenting to salvage a LIMA graft. Ann Thorac Surg 1999;68:2333-2334.

3. Tan JW, Johan BA, Cheah FK, et al. Coronary subclavian steal syndrome: a rare cause of acute myocardial infarction. Singapore Med J 2007;48:5-8.

4. Chavan A, Mügge A, Hohmann $C$, et al. Recurrent angina pectoris in patients with internal mammary artery to coronary artery bypass: treatment with coil embolization of unligated side branches. Radiology 1996;200:433-436.

5. Elian D, Gerniak A, Guetta V, et al. Subclavian coronary steal syndrome: an obligatory common fate between subclavian artery, internal mammary graft and coronary circulation. Cardiology 2002;97:175-179.

6. Douglas P. Braunwald's heart disease. In: Zipes D, Libby $P$, Bonow R, Braunwald $E$, editors. 7th ed. Endovascular treatment of noncoronary obstructive vascular disease; 2005.p. 1474-1477.

7. Oslen CO, Dunton RF, Maggs PR, et al. Review of the coronary-subclavian steal following internal mammary artery coronary artery by-pass surgery. Ann Thorac Surg 1988;46:675-678. 
8. Wright IA, Laing AD, Buckenham TM. Coronary subclavian steal syndrome: non-invasive imaging and percutaneous repair. Br J Radiol 2004;77:441444.

9. Filippo $F$, Francesco $M$, Francesco $R$, et al. Percutaneous angioplasty and stenting of left subclavian artery lesions for the treatment of patients with concomitant vertebral and coronary subclavian steal syndrome. Cardivasc Intervent Radiol 2006;29:348-353.

10. Georges NP, Ferreti JA. Percutaneous transluminal angioplasty of subclavian artery occlusion for treatment of coronary subclavian steal. AJR Am J Roentgenol 1993;161:399-400. 